The University of San Francisco

USF Scholarship: a digital repository@ Gleeson Library |

Geschke Center

Philosophy

College of Arts and Sciences

$1-12-2011$

\title{
What 'Biological Racial Realism’ Should Mean
}

Quayshawn Spencer

University of San Francisco, qnspencer@usfca.edu

Follow this and additional works at: http://repository.usfca.edu/phil

Part of the Philosophy Commons

\section{Recommended Citation}

Spencer, Quayshawn, "What 'Biological Racial Realism' Should Mean" (2011). Philosophy. Paper 11.

http://repository.usfca.edu/phil/11

This Article is brought to you for free and open access by the College of Arts and Sciences at USF Scholarship: a digital repository @ Gleeson Library | Geschke Center. It has been accepted for inclusion in Philosophy by an authorized administrator of USF Scholarship: a digital repository @ Gleeson

Library | Geschke Center. For more information, please contact repository@usfca.edu. 


\section{What 'Biological Racial Realism' Should Mean \\ Quayshawn Spencer \\ forthcoming in Philosophical Studies}

\section{Introduction}

Over the past decade or so, a curious ambiguity has arisen in the race debate. That ambiguity is what is actually meant by 'biological racial realism'. So far, philosophers have either meant 'race is a natural kind in biology' or 'race is a real biological kind', but there are multiple, incompatible views about what a natural kind or a real biological kind is supposed to be. The goal of this paper is to defend a new and more promising interpretation of 'biological racial realism' for use in the race debate. That interpretation is that 'race is a genuine kind in biology'.

The paper is divided into five parts. First, I will begin by motivating the problem. Here I will explain what the race debate is about and highlight its ambiguities. I will focus on how it is ambiguous with respect to what is meant by 'biological racial realism', and explain how clearing up this particular ambiguity will be an important contribution to the race debate. Second, I will introduce the idea of a genuine kind, clarify how it is a different kind of kind from each kind of kind currently used in the race debate, and show how it can underwrite an altogether different interpretation of 'biological racial realism'.

Third, I will present an argument that defends my interpretation of 'biological racial realism' as the best one for the race debate, and then defend each premise of the argument. Along the way, I will raise and respond to a few salient objections to each premise. Fourth, I will present some interesting consequences of my view for the race debate. Fifth, I will conclude by summarizing the paper. 


\section{The Many Meanings of 'Biological Racial Realism'}

The race debate is a debate in the philosophy of race that attempts to answer basic metaphysical questions about race, such as, 'What is a race?', 'Is race real?', and 'At what level of reality is race real if it is real?'. From Kant to Du Bois to Appiah, these questions have been central in the philosophy of race. While the race debate, as I am characterizing it, is a metaphysical debate, there is a normative debate about race talk that some philosophers believe is intimately tied to the metaphysical debate about race. This debate concerns how we ought to use racial discourse in order to achieve social justice. However, when I talk about 'the race debate', I will only be referring to the metaphysical debate about race.

As others have pointed out before—-such as Sally Haslanger (2008, 58-59) and Joshua Glasgow $(2009,4-5)$ — the standard positions in the race debate are threefold. First, some defend racial anti-realism, which is the view that race is not real; while others defend racial realism, which is the view that race is real. Historically, racial realism has had two different defenses. Some argue for social constructivism, which claims that race is a social construct. Others argue for biological racial realism, which claims that race is biologically real. The three standard positions in the race debate, along with some examples of proponents, are given in Table 1. 


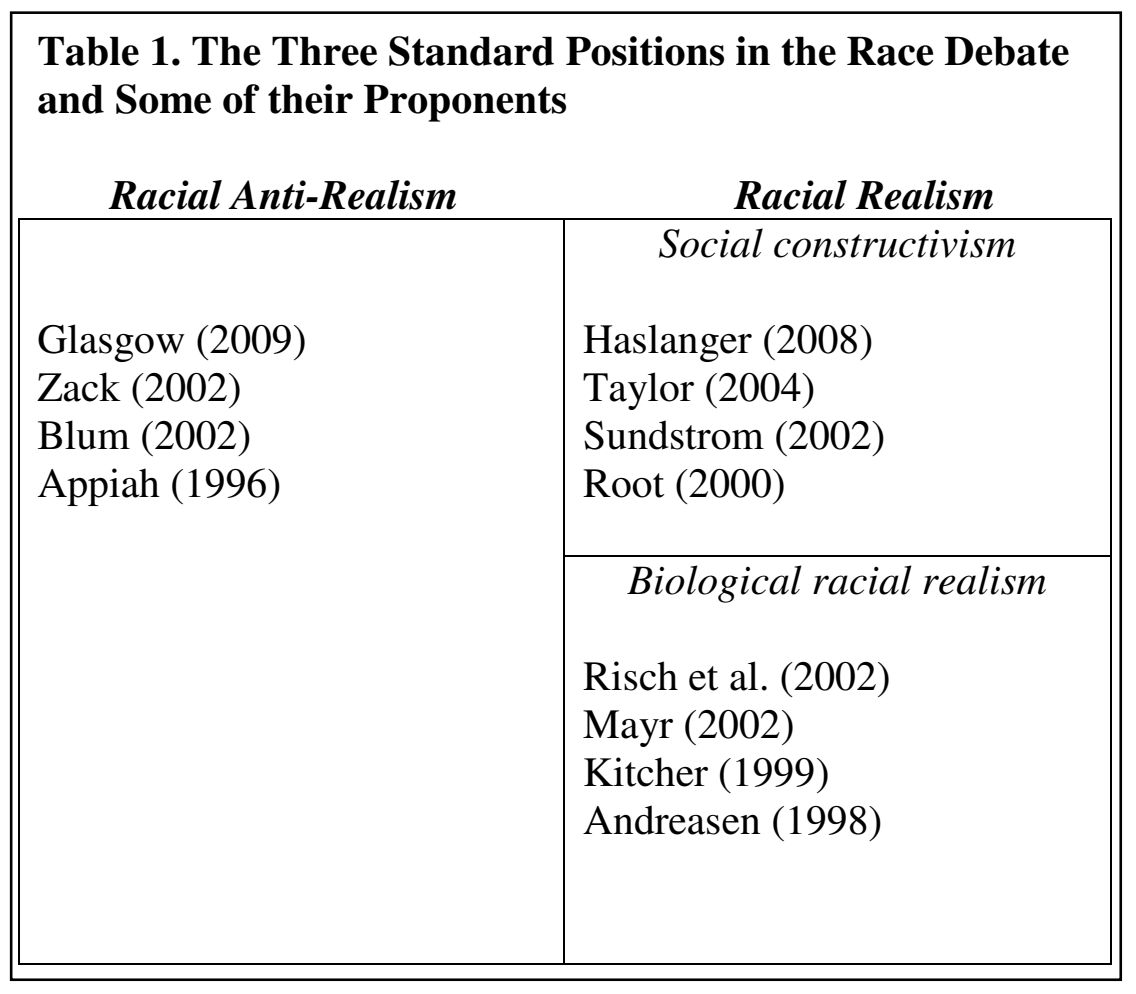

Although the race debate sounds clear and precise, the devil is in the details. There is considerable ambiguity in what is meant by 'social constructivism', and it is also ambiguous what meaning of 'race' the race debate is supposed to be about. These are all worthwhile concerns. However, my focus will be on the ambiguity in what is meant by 'biological racial realism', since its clarity is important to the race debate, yet philosophers have paid relatively little attention to its ambiguity.

Historically, 'biological racial realism' has been interpreted in either one of two ways. One is 'race is a natural kind in biology', and the second is 'race is a real biological kind'. However, race theorists adopt at least four different views about what a natural kind is, and at least two different views about what a real biological kind is. Let me begin with the natural kind views. 
First, some race theorists—-such as Anthony Appiah (1996, 40), Robin Andreasen (2000, S655-S657), and Naomi Zack $(2002,4)$ —define a natural kind as an objectively real kind. A paradigm example is Andreasen's view. According to Andreasen (2000, S655), race must be a "natural kind" in order to be biologically real. Furthermore, natural kinds are supposed to be kinds that "exist objectively"; and more specifically, kinds that exist "independently of human classifying activities" (Andreasen 2000, S656-S657).

Second, some race theorists—-such as Edouard Machery $(2005,446)$ and Glasgow $(2009$, 81)_define a natural kind as an inductively useful kind in science. For example, Machery (2005, 445, 446) defines "natural kinds" as "classes about which nonaccidental, scientifically relevant inductive generalizations can be formulated", and Machery and Faucher $(2005,1209)$ go on to require that race must have "inferential power" in order to be biologically real.

Third, some race theorists define a natural kind as a kind that is a useful object of study in a natural science. For example, Haslanger $(2008$, 58) claims that biological racial realism requires that "races are natural kinds," and she goes on to define a natural kind as a kind whose constitutive properties are "natural", where "natural properties of things are ... those studied by the natural sciences" (Haslanger 2008, 60).

Fourth, some race theorists define a natural kind using pragmatism. Philip Kitcher is the main proponent of this view. Kitcher $(2007,299,301)$ rejects that there are any objectively real kinds in nature. Instead a kind is natural to the extent that it is constructed by lumping objectively real particulars into a kind $\kappa$ such that $(\mathrm{N} 1) \kappa$ is useful for some valuable project $P$ in some scientific context $C$, and (N2) א's P-utility in C outweighs its "potential damage", not just in C, but in other contexts in which $\kappa$ plays a role (Kitcher 2007, 302). For example, according to Kitcher $(2007,306)$, in order for race to be a natural kind in biology, it would not only have to 
prove itself useful for some important biological project, but also, we must be able to show that its use would not "revive unjust and damaging social practices". For clarity, let me call objectively real kinds, inductively useful scientific kinds, kinds that are useful objects of study in natural science, and kinds that satisfy (N1) and (N2): natural ${ }_{\mathrm{o}}$ kinds, natural $\mathrm{i}_{\mathrm{i}}$ kinds, natural $\mathrm{u}_{\mathrm{u}}$ kinds, and natural $\mathrm{p}_{\mathrm{p}}$ inds, respectively.

As for real biological kinds, there are two views. The first is Ronald Sundstrom's. According to Sundstrom $(2002,93,94,101)$, a "real biological kind" is a kind that occurs "independently of human interest", and whose members are united by "some significant biological relation", such as "common lines of descent". The second view comes from Glasgow. According to Glasgow $(2009,82)$, a "real biological kind" is a kind that has "some biologically principled basis". Although Glasgow does not provide a positive account of what a biologically principled kind is, he does say what it is not. According to Glasgow, a kind is not biologically principled if it is "biologically arbitrary", and a kind is biologically arbitrary just in case "the biological facts do not give us sufficient reason to mark off that kind" (Glasgow 2009, 82). For clarity, let me call Sundstrom's kind of real biological kind and Glasgow's kind of real biological kind a 'real ${ }_{\mathrm{i}}$ biological kind' and a 'real $\mathrm{p}_{\mathrm{p}}$ biological kind', respectively.

Actually, we can lump the kinds of kinds race theorists talk about into three metaphysical groups from the viewpoint of the natural kind realism debate. By 'the natural kind realism debate', I mean the overarching debate in philosophy of science about whether a subgroup of scientific kinds consists of objectively real kinds; where an objectively real entity is typically considered to be one that exists independently of human thought and language (Psillos 2002, xix; Barrett 2007, 527-528, 545). Natural kind realists, such as Stathis Psillos (2002, xvii-xxv, 284300 ), argue that as a matter of fact such a subgroup exists, and it contains kinds such as virus, 
oxygen, $\mathrm{H}_{2} \mathrm{O}$, and other kinds posited by our "most mature and genuinely successful scientific theories". Natural kind anti-realists, such as Philip Kitcher (2007, 301), argue that while scientific kinds might be real in some sense, none are objectively real, since "there are no privileged fault lines ... in nature."

Suppose we call kinds of kinds that a natural kind realist would adopt 'realist kinds' insofar as they count as objectively real kinds. Furthermore, let us suppose that 'anti-realist kinds' are kinds of kinds that a natural kind anti-realist would adopt insofar as they count as real, but not objectively real kinds. Last, let me coin a new term 'agnostic kind' to describe the kinds of kinds that lie neutral in the natural kind realism debate insofar as they are kinds of kinds that are real in some sense, but whose nature does not entail objective or non-objective reality. ${ }^{1}$ By that I do not mean to say that agnostic kinds have neither objective nor non-objective reality, but only that one cannot tell whether an agnostic kind is objectively or non-objectively real from its nature.

From the distinctions I have made above, we can easily classify the kinds of kinds that race theorists talk about into realist, anti-realist, and agnostic kinds. Namely, natural ${ }_{\mathrm{o}}$ kinds and

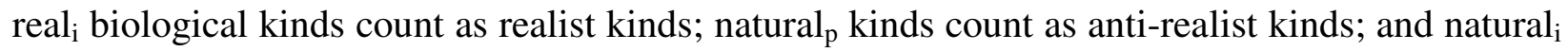
kinds, natural $\mathrm{u}_{\mathrm{u}}$ kinds, and real $\mathrm{p}_{\mathrm{p}}$ biological kinds count as agnostic kinds. This means that there are three broad metaphysical interpretations of 'biological racial realism' in the race debate, and six particular metaphysical interpretations.

As we can see, there are many different versions of biological racial realism floating around. Moreover, it seems clear that race theorists interpret biologically real kindhood according to how they lean in the natural kind realism debate. Race theorists that lean toward

\footnotetext{
${ }^{1}$ I owe the term 'agnostic kind' to Tommie Shelby.
} 
natural kind realism, such as Andreasen and Zack, interpret a biologically real kind as some sort of realist kind. However, race theorists that lean toward natural kind anti-realism or natural kind agnosticism, such as Haslanger and Kitcher, interpret a biologically real kind as some sort of an agnostic or anti-realist kind.

Be this as it may, it would be nice to have a single, agreed upon account of biologically real kindhood that could be used to interpret 'biological racial realism' in the race debate. But also, it would be nice if that account was motivated by its appropriateness in the race debate, as opposed to merely being a hangover from our proclivities in the natural kind realism debate. So as to inch us closer to both goals, I will offer a new kind of kind to use in the race debate. I call it a 'genuine kind'.

\section{Genuine Kinds}

Consider some paradigm cases of good scientific classification. Some examples would be $\mathrm{H}_{2} \mathrm{O}$, electron, gene, and monophyletic group. I trust that most people are familiar with $\mathrm{H}_{2} \mathrm{O}$, electron, and gene, but not so much with monophyletic group. A monophyletic group is a fundamental genealogical unit in cladistics, which is the scientific research program (SRP) in systematic biology that aims to classify organisms in a purely genealogical way. A monophyletic group is defined as an ancestor and all of its descendants. For example, provided that Sasha and Malia Obama are all of Barack Obama's children, the group consisting of Barack, Sasha, and Malia Obama is a monophyletic group.

Now consider some paradigm cases of bad scientific classification. Some examples would be gemmule, baramin, and destructiveness organ. I trust that gemmule, baramin, and destructiveness organ are all unfamiliar scientific kinds. The gemmule was a rival unit of heredity in $19^{\text {th }}$ century biology that was proposed by Charles Darwin to explain the inheritance 
of acquired characteristics. Gemmules, unlike genes, originate in somatic cells and travel to the reproductive organs to develop into gametes. The baramin is the fundamental unit of biodiversity in baraminology, which is the field of creation science that studies biodiversity. A baramin is defined as a created kind from God's biological creation. Finally, the destructiveness organ was a kind in phrenology. The destructiveness organ was a faculty of the brain wholly dedicated to producing impulses and desires to injure or destroy existing structures.

Now, what do kinds in the first group have in common that kinds in the second group lack? They are all kinds that contributed to long-term scientific progress. By 'long-term scientific progress' I mean scientific progress that went beyond a theoretical paradigm in a specific SRP, and even beyond a specific SRP. Also, by 'scientific progress' I mean epistemic progress in science, such as improving our ability to predict known phenomena, or accurately predicting novel phenomena.

For example, destructiveness organ did not contribute to long-term scientific progress because whatever epistemic achievements we got out of it did not extend beyond phrenology. On the other hand, gene did contribute to long-term scientific progress because the epistemic progress we achieved with it carried right on over to molecular genetics after geneticists gave up Mendelian genetics. ${ }^{2}$ Hence, there is a fundamental epistemic distinction between kinds of kinds in science. Some kinds are appropriate for ongoing scientific research, while the rest are not. Or said in a different way, some kinds do not lead scientists down dead ends, or as George Smith $(2002,162)$ would say, "garden paths", while the rest of them do. ${ }^{3}$

\footnotetext{
${ }^{2}$ Buchwald and Smith $(2001,469)$ call such a phenomenon "continuity of evidence".

3 According to Smith $(2002,162)$ a "garden path" is a stretch of scientific activity that ends in discontinuity of evidence.
} 
Although nobody can infallibly predict which kinds will contribute to long-term scientific progress, there are better and worse ways of classifying objects if picking kinds of that sort is one's goal—as it should be in modern science. Let me propose genuine kinds as our best estimate of kinds that will contribute to long-term scientific progress-where a genuine kind is a valid kind in a well-ordered SRP. While I borrow the term 'genuine kind' from Goodman (1955, 119), and while Goodman's work on kinds inspired my view, the idea of a genuine kind is distinct from what Goodman had in mind. ${ }^{4}$ So let me clarify the idea of a genuine kind. I will clarify the idea of a valid kind in an SRP first, and then the idea of a well-ordered SRP. Along the way, I will point out how genuine kinds differ from each kind of kind currently adopted in the race debate.

First, insofar as a kind is a group of actual or possible members defined by common properties or relations among its members, a valid kind in an SRP is a kind that is useful for playing an epistemic role of scientific kinds in that SRP, as well as a kind that is adequately epistemically justified in its SRP. Now let me explain what a valid kind in an SRP is in some detail.

First and foremost, a valid kind in an SRP must be useful for playing an epistemic role of scientific kinds in its SRP. ${ }^{5}$ So not just any sort of usefulness will do. A valid kind in an SRP must possess epistemic usefulness. For example, a kind could be introduced into an SRP for

\footnotetext{
${ }^{4}$ For example, Goodman $(1978,128)$ eventually identifies genuine kinds as "categories that are right for science in general." However, he provides no account of what sort of kind is 'right for science in general'. My account of genuine kindhood will do just that.

${ }^{5}$ See Boyd $(1999,148-150)$ for a similar account of why kinds are introduced into science.
} 
economic gain, but that does not make it a valid kind in that SRP. ${ }^{6}$ The reason why valid kinds in SRPs are required to possess epistemic usefulness is because it is only in virtue of its epistemic usefulness that scientists have an empirical reason to posit a kind's existence in the first place.

But also, notice that a valid kind in an SRP must be useful for playing an epistemic role of scientific kinds. Scientific kinds do specific sorts of epistemic work in science. Like ordinary kinds, scientific kinds are used to expand singular claims into generalizations. However, in science, the sorts of generalizations that kinds underwrite are of three specific sorts: observational laws, theories, and presuppositions. So let me say a bit about how scientific kinds are used to ground observational laws, theories, and presuppositions in order to elucidate how valid kinds in SRPs function as epistemically useful scientific kinds.

The first epistemic role that scientific kinds play is underwriting observational laws; by which I mean observational generalizations that are robust in a specific epistemic context. Thus a kind can be valid in an SRP in part because it helps scientists in that SRP generate observational regularities that are important for understanding that realm of the world. Philosophers tend to call this role 'inductive usefulness'? However, since inductive generalizations need not be observational laws, and, as I will explain later, observational laws need not be inductive generalizations, I will call this role 'observational usefulness'. Nevertheless, here is an example of a scientific kind grounding an inductive observational law.

Consider the observational law in biochemistry that enzymes tend to lose catalytic function in alcohol solvents, where an "enzyme" is a protein catalyst and an "alcohol" is an

\footnotetext{
${ }^{6}$ I owe this example to Rae Langton.

${ }^{7}$ For example, see Boyd (1999, 146), Häggqvist (2005, 72), and Machery $(2005,446)$.
} 
organic molecule with a hydroxyl functional group. The phenomenon is called 'alcohol-induced denaturation of enzymes'. ${ }^{8}$ Notice that without recognizing certain kinds, such as enzyme and alcohol, it would be impossible even to observe this law. Instead, all biochemists could say is that certain catalysts in living things, such as catalase, tend to lose catalytic function in certain organic solvents, while others, such as $\mathrm{Cu}^{2+}$, do not.

The second epistemic role that scientific kinds play is underwriting theories. Philosophers tend to call this role 'explanatory usefulness'. However, it should be noted that scientific kinds can play this role without actually helping to explain anything. ${ }^{10}$ This is why I prefer to call this role 'theoretical usefulness'. Nevertheless, an easy example of scientific kinds playing a theoretical role is in the biochemical explanation for alcohol-induced denaturation of enzymes.

The explanation is supposed to unfold in the following way. First, since most enzymes obtain their catalytic function from their three-dimensional (3D) structure, and since all enzymes are proteins, alcohol must disturb the 3D-structure of proteins in order to inactivate most enzymes. Second, we know that the 3D-structure of proteins arises from weak electromagnetic bonding that always includes hydrogen bonding, and we know that alcohols vigorously engage in hydrogen bonding. Thus, it is highly likely that when proteins and alcohols come into contact,

${ }^{8}$ That alcohol deactivates enzymes is why tending to an open wound with alcohol disinfects it. The alcohol enters bacterial cells that have landed on the wound and deactivates enough bacterial enzymes to kill the bacteria, thus leaving the wounded area "disinfected".

${ }^{9}$ For example, see Boyd (1999, 146) and Psillos $(2002,258)$.

${ }^{10}$ See Häggqvist (2005) for a defense of how scientific kinds can be theoretically useful without being explanatorily useful. 
alcohols replace enough intra-protein hydrogen bonds with alcohol-protein hydrogen bonds to disfigure $3 \mathrm{D}$ protein structure, which deactivates the catalytic function of most enzymes. Now even if that explanation sounded a bit esoteric, the point is that without various additional kinds, such as electromagnetic bond and hydrogen bond, biochemists could not have generated the explanation above.

The third, and less discussed, epistemic role of scientific kinds is underwriting presuppositions of experience, such as fundamental laws and definitions. ${ }^{11}$ We can call this sort of epistemic usefulness 'presuppositional usefulness'. For example, consider Newton's $8^{\text {th }}$ definition in the Principia, which is his definition of 'motive force' as "the force proportional to a body's quantity of motion in a given time" (Newton 1999, 407). ${ }^{12}$ Thus definition 8 is where we find the famous ' $F=m a$ ' claim in classical mechanics, although Newton's version was clearly not in the form of an equality and used the concepts of momentum and time instead of mass and acceleration.

Definition 8 was not introduced as an observational law, or as a theory, but rather, as a stipulation that served to constrain possible experience in classical mechanics. For instance, if a body had a motive force causing its motion, then we know, from definition 8 , that that force's magnitude is directly proportional to the body's change in momentum in a given time, or said otherwise, its mass and acceleration. Therefore, kinds of physical quantities such as motive force, momentum, mass, and acceleration were all what we can call 'presuppositional kinds', since they were all useful in grounding presuppositions in an SRP.

11 Although it is less discussed, some philosophers have paid considerable attention to presuppositions in science. For example, see Boyd (1999, 176-179) and Friedman (2001).

12 Today we call a motive force a 'net force' and quantity of motion 'momentum'. 
Notice that, right away, we can see that genuine kinds are different from natural ${ }_{i}$ kinds, natural $_{\mathrm{o}}$ kinds, real $_{\mathrm{i}}$ biological kinds, and natural $\mathrm{u}_{\mathrm{u}}$ kinds. Genuine kinds are different from natural $_{i}$ kinds because genuine kinds can be epistemically useful without being inductively useful. How can that be? Supposing that an induction is a generalization or prediction inferred from a sample, it just so happens that some kinds have members that are too hard to isolate, and so the kind itself resists inductive usefulness. However, the latter does not exclude such kinds from being epistemically useful as scientific kinds, since they can be abductively useful for generating observational laws or theories.

A good example of such kinds is superheavy elements in nuclear chemistry. Superheavy elements, such as elements $110-118$, tend to possess just a few synthesizable isotopes, and even then, the isotopes that nuclear chemists can synthesize only stick around for fractions of a second, which is far too little time to use the isotopes to generate inductions about their respective elements. ${ }^{13}$ However, superheavy elements are still abductively useful as the most likely products of certain nuclear fusion reactions and abductively useful as the most likely starting elements of certain nuclear decay chains, which makes superheavy elements observationally useful in grounding certain nuclear chemical phenomena.

But also, genuine kinds differ from natural ${ }_{\circ}$ kinds insofar as nothing about natural ${ }_{o}$ kindhood guarantees that a natural ${ }_{0}$ kind will be epistemically useful as a scientific kind. Proponents of natural ${ }_{\circ}$ kinds typically assume that ontological objectivity and epistemic usefulness as a scientific kind go hand-in-hand. For example, Andreasen $(1998,205)$ conflates "theoretically interesting" and "objective feature of the world" in her defense of why we should

\footnotetext{
${ }^{13}$ An isotope is an alternative form of an element with a unique number of neutrons.
} 
use natural $l_{0}$ kinds in the race debate. But natural ${ }_{o}$ kinds need not be theoretically or otherwise epistemically useful as a scientific kind.

The explanation is simple. Science is a human endeavor, and even if there are objectively real kinds out there, there is no guarantee that humans will have epistemic access to every objectively real kind there is, or even any objectively real kind that there is. In other words, even if there are objectively real kinds, some or all of them could lie outside of our epistemic reach. However, genuine kinds are defined in such a way that only kinds within our epistemic reach count as genuine kinds, which is enough to show that genuine kinds and natural ${ }_{\mathrm{o}}$ kinds are distinct kinds of kinds.

As for natural $\mathrm{u}_{\mathrm{u}}$ kinds, genuine kinds and natural $\mathrm{u}_{\mathrm{u}}$ kinds are distinct because genuine kind theory is unambiguous about what sort of usefulness makes a kind genuine, whereas natural ${ }_{u}$ kind theory is ambiguous about what sort of usefulness makes a kind natural $\mathrm{u}_{\mathrm{u}}$. As a result, a kind could be a useful object of study in a natural science for moral or economic reasons, whereas that same usefulness would not qualify that kind as a genuine kind. The same applies to real ${ }_{i}$ biological kinds. Real $\mathrm{i}_{\mathrm{i}}$ biological kind theory is unclear about what sort of significance is

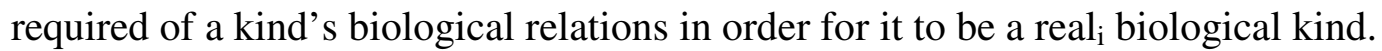

After a kind is determined to be useful for some epistemic role of scientific kinds in an $\mathrm{SRP}$, in order to inch one step closer to being a valid kind in that SRP, that kind must be adequately epistemically justified in that SRP. There are two ways to adequately epistemically justify a kind in an SRP, and each way corresponds to the sort of epistemic usefulness that the kind is supposed to have in its SRP. From the point of view of how to justify kinds in SRPs, there are really just two kinds of epistemically useful scientific kinds. But in order to make that distinction I will need to borrow a bit of jargon from George Smith. 
According to Smith $(2002,159)$, observational laws come in two types from the viewpoint of the SRP in which it is a law. The first is observational laws that do not depend on any theory in their respective SRPs. Smith calls such laws "first-order phenomena". The second is observational laws that depend on at least some theory in their respective SRPs for their formulation. Smith calls such laws "second-order phenomena". For example, the law that the moon orbits the earth with a period of about 30 days was a first-order phenomenon in classical mechanics because it did not depend on any theory in classical mechanics in order to observe. However, the law that the sun wobbles around the center of gravity of our planetary system every 15 years or so was a second-order phenomenon in classical mechanics because this law presupposes the theory of universal gravity in its formulation.

With that said, and from the point of view of how to justify kinds in SRPs, the two kinds of epistemically useful scientific kinds are kinds that underwrite presuppositions or first-order phenomena, and kinds that do not underwrite presuppositions or first-order phenomena, but do underwrite theories or second-order phenomena. ${ }^{14}$ Kinds from the first group need to be justified independently of the observational laws of their respective SRPs. Kinds from the second group depend on an appeal to the observational laws in their respective SRPs in order to adequately justify them. The reason for this difference in justifiability is simple. First, kinds from the first group cannot be justified by an appeal to observational laws on pains of circularity, since such kinds make observational laws possible. In contrast, kinds from the second group essentially

\footnotetext{
${ }^{14}$ Notice that this distinction implies that kinds in the first group can underwrite theories and second-order phenomena. However, the latter usefulness is parasitic on a prior usefulness in underwriting presuppositions or first-order phenomena.
} 
underwrite or depend on some theory, and since theories must explain or predict observational laws in order to be warranted, so too must the kinds that underwrite or depend on them.

Perhaps it would be useful to help ourselves to Michael Friedman's $(2001,72)$ jargon of "relativized a priori" and "properly empirical" to describe this epistemic distinction between scientific kinds. We can call kinds whose epistemic usefulness in an SRP lies in underwriting presuppositions or first-order phenomena in that SRP 'relativized a priori kinds', and kinds whose epistemic usefulness in an SRP lies only in underwriting theories or second-order phenomena in that SRP 'properly empirical kinds'. This is not to say that both kinds of kinds are not ultimately empirically justified, but just to say that relative to a specific SRP, a kind can require a very different sort of justification both in terms of its dependence on the observational laws of that SRP and in terms of its distance from empirical support. ${ }^{15}$

That the distinction between properly empirical and relativized a priori kinds has not been made before in philosophical discussions about scientific kinds is an interesting fact, and one that will have important consequences for the race debate since many contemporary biological theories of race are theories of subspecies, and subspecies is a relativized a priori kind since it is the sort of kind that is used to ground presuppositions and make observational laws possible in various biological research programs. Now let me say a bit about how relativized a priori and properly empirical kinds can be adequately epistemically justified in an SRP.

If a kind is being proposed as a relativized a priori kind in an SRP, then that kind is justified in that SRP just in case it is defined in a way that is well-motivated according to the

${ }^{15}$ In other words, the notion of a priori that I am invoking here is not "justified independently of experience", but is rather, "constitutive of the concept of the object of ... knowledge" (Friedman 2001, 71-72). 
aims and epistemic values of that SRP. Furthermore, since achieving empirical adequacy, in van Fraassen's sense, is presumably an aim of any SRP, relativized a priori kinds can still be seen as empirically motivated if their adoption allows their SRP to inch closer to empirical adequacy.

A good example of an adequately epistemically justified relativized a priori kind is monophyletic group in cladistics. Monophyletic group is justified in cladistics because it is uniquely useful for defining 'higher taxon' in cladistics. Cladists define a higher taxon as a monophyletic group of species. There are rival kinds that cladists could use to define 'higher taxon', such as paraphyletic group or polyphyletic group. ${ }^{16}$ However, only monophyletic group best satisfies cladistic aims and epistemic values.

For instance, one extremely important cladistic aim that monophyletic group helps cladists achieve is erecting a purely genealogical and hierarchical classification of taxa. Although paraphyletic and polyphyletic definitions of 'higher taxon' enable a hierarchal classification of taxa, neither enables a purely genealogical classification of taxa. This is one major reason why monophyletic group is a valid relativized a priori kind in cladistics while neither paraphyletic nor polyphyletic group are. ${ }^{17}$

\footnotetext{
${ }^{16}$ A paraphyletic group is an ancestor and some, but not all, of its descendants. A polyphyletic group is an ancestor and descendants such that one or more of the descendants do not descend from the ancestor that defines the group. For example, the group consisting of Barack and Sasha Obama is a paraphyletic group because it is missing Malia Obama. Furthermore, the group consisting of Barack, Sasha, and Malia Obama plus myself is a polyphyletic group because Barack Obama is not an ancestor of mine.

17 Another reason why monophyletic group is justified in cladistics is because it promotes empirical adequacy in cladistic classification.
} 
Now if a kind is being proposed as a properly empirical kind in an SRP, then that kind is justified in that SRP just in case its kindhood is warranted to explain or predict observational laws in the SRP. By that I mean, given the epistemic values of and the observational laws in an SRP, a properly empirical kind is justified in that SRP iff it is needed to explain or predict some subset of those observational laws. A good example of an adequately epistemically justified properly empirical kind is the gene in classical genetics.

The gene was introduced by Gregor Mendel to generate theories that precisely predicted a multitude of observational laws about heredity. It should be noted that there were other units of heredity that biologists were promoting at the time Mendel introduced the gene, such as Darwin's gemmule, Herbert Spencer's physiological unit, and August Weismann's id. However, none of them were justified to use in classical genetics because only the gene permitted quantitatively precise predictions of hereditary phenomena, and no other proposed unit of heredity promoted as much empirical accuracy as the gene. Since quantitative precision and empirical accuracy were epistemic virtues in classical genetics, the gene was justified to play the role of the unit of heredity in classical genetics while neither the gemmule, the physiological unit, nor the id were justified to play that role.

Now that we fully understand what it means to be a valid kind in an SRP, we can distinguish between genuine kinds and natural $p_{p}$ kinds as well as genuine kinds and real $p_{p}$ biological kinds. Genuine kinds are distinct from natural ${ }_{\mathrm{p}}$ kinds because a kind does not need to

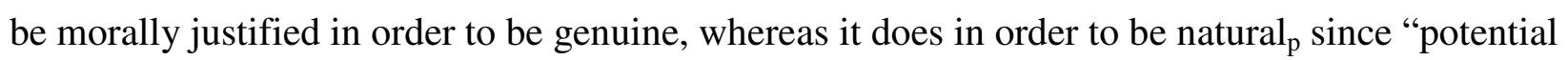
damage" in (N2) is a morally loaded phrase. For example, nuclear bomb would be a genuine kind in nuclear physics, but not a natural ${ }_{p}$ kind. 
As for the difference between genuine and real ${ }_{p}$ biological kinds, remember that a kind is not real ${ }_{\mathrm{p}}$ in biology if "the biological facts do not give us sufficient reason to mark off that kind" (Glasgow 2009, 82). In fact, in Glasgow's analysis of biological candidates for race, he rejects some of them because they are "underdetermined by the biological facts" (Glasgow 2009, 106). However, genuine kind theory acknowledges upfront that "the biological facts" are always insufficient to mark off kinds. ${ }^{18}$ This is because epistemic values play a crucial role in identifying genuine kinds. For example, since no amount of biological facts provides biologists with "sufficient reason" to adopt monophyletic group, monophyletic group does not count as a real $_{\mathrm{p}}$ biological kind. However, monophyletic group still counts as a genuine kind since it turns out to be well-motivated in cladistics according to cladistic aims and epistemic values.

So, to recap, a valid kind in an SRP is a kind that is useful for playing an epistemic role of a scientific kind in that SRP, such as grounding an observational law, theory, or presupposition in that SRP, and a kind that is adequately epistemically justified in that SRP, which, if it is a relativized a priori kind means that it is justified in a way that is well-motivated by the aims and epistemic values of the SRP, and if it is a properly empirical kind means that it is warranted to explain or predict one or more observational laws of the SRP. However, being a valid kind in an SRP is just the first half of being a genuine kind. So let me discuss the second half ... a genuine kind's reality in a well-ordered SRP.

Notice that paradigm cases of good scientific classification do not come from just any old sort of science, they come from SRPs. Electron comes from particle physics, gene comes from genetics, monophyletic group comes from cladistics, and so forth. This is because, as Kuhn and

\footnotetext{
${ }^{18}$ Here I am assuming that by "biological facts" Glasgow means observational laws or theories in biology.
} 
Lakatos first noted, SRPs—or 'disciplinary matrices' in Kuhn's jargon—tend to be powerful engines for obtaining scientific progress. However, not just any old SRP is apt to obtain scientific progress. After all, craniometry, phrenology, and creation science were all SRPs at some point in time. This is where the well-orderliness constraint comes in. In order to be a genuine kind, that kind's host SRP must be well-ordered. Furthermore, an SRP is well-ordered just in case it is organized in such a way as to significantly increase its chance of obtaining longterm scientific progress. Historically, well-orderliness has been achieved by safeguarding an SRP in three different ways.

First, well-ordered SRPs tend to have coherent and well-motivated aims. An example of an SRP that is not well-ordered due to an incoherent aim is phenetics. Phenetics is an SRP in systematic biology that aims to classify taxa exclusively according to overall similarity. However, as some philosophers have argued, obtaining a taxonomy based on overall similarity is not just an unreachable ideal, it is conceptually incoherent. Let me clarify what these philosophers mean.

Given that a similarity is a property or relation shared by at least two objects but not a third, pheneticists posit that for any three organisms, $A, B$, and $C$, there are three sets of similarities that exist, $S_{A B}, S_{A C}$, and $S_{B C}$, which correspond to the similarities between A and B but not $\mathrm{C}, \mathrm{A}$ and $\mathrm{C}$ but not $\mathrm{B}$, and $\mathrm{B}$ and $\mathrm{C}$ but not $\mathrm{A}$, respectively. Now if a pheneticist says that $A$ and $B$ are more similar to each other overall than to $C$, what she means is that $\left|S_{A B}\right|>\left|S_{A C}\right| \&$ $\left|\mathrm{S}_{\mathrm{AB}}\right|>\left|\mathrm{S}_{\mathrm{BC}}\right|{ }^{19}$ Furthermore, pheneticists have developed dozens of statistics to estimate overall similarity.

${ }^{19}$ For any set $A$, 'IAl' is shorthand for 'the number of elements in $A$ '. 
However, as Elliott Sober (1993, 167-168) points out, phenetics is doomed from the start because there simply is no fact of the matter about the total number of similarities that two objects share in comparison to a third. In other words, the idea of $\mathrm{S}_{\mathrm{AB}}, \mathrm{S}_{\mathrm{AC}}$, and $\mathrm{S}_{\mathrm{BC}}$ is nonsense. The reason is simple. Since some relations and properties are observer-dependent, and the number of observers of a similarity is not a fixed quantity, the total number of similarities that two objects share in comparison to a third is not a fixed quantity either, which renders any measure of overall similarity a mere confusion. ${ }^{20}$

Rather, what pheneticists need to do if they wish to make their research program coherent is use only certain similarities for phenetic classification, and make sure that the class of similarities they use permit a unique assignment of values to $\left|S_{\mathrm{AB}}\right|$, $\mid \mathrm{S}_{\mathrm{AC}} \mathrm{l}$, and $\left|\mathrm{S}_{\mathrm{BC}}\right|$ for any three organisms A, B, and C. Until then, pheneticists are just arbitrarily classifying organisms-at least from a metaphysical point of view—which is not a recipe for achieving long-term scientific progress.

Second, well-ordered SRPs tend to have competitive predictive power. By 'predictive power' I mean 'ability to predict known phenomena and ability to predict novel phenomena'. For example, creation science is not well-ordered in part because its predictive power is not competitive with evolutionary biology. Creationists can accommodate a fair amount of known phenomena, but they do not have a good track record of making accurate novel predictions.

Third, well-ordered SRPs tend to use rigorous cross-checks; where a cross-check is a double check of research results using different background assumptions. This could come from conducting different experiments, using different experimenters, requiring a thorough criticism

\footnotetext{
${ }^{20}$ Another way of putting Sober's point is that $\mathrm{S}_{\mathrm{AB}}, \mathrm{S}_{\mathrm{AC}}$, and $\mathrm{S}_{\mathrm{BC}}$ are not sets since each one's membership changes depending on the observer.
} 
of research before accepting it, or so forth. For example, craniometry was not well-ordered in part because it lacked what Helen Longino $(1990,76)$ would call "transformative criticism". In other words, the problematic background assumptions that crucially figured in craniometric research were not criticized by craniometrists, presumably because craniometrists were antecedently convinced of research results that fit their world views.

So, to recap, a genuine kind is a valid kind in a well-ordered SRP. But, more specifically, we can say that a genuine kind is a kind $\kappa$ in a scientific research program $P$ that satisfies (G1)(G3):

(G1) $\kappa$ is useful for playing an epistemic role of scientific kinds in $\mathrm{P}$, such as underwriting an observational law, theory, or presupposition in $\mathrm{P}$.

(G2) $\mathrm{K}$ is adequately epistemically justified in $\mathrm{P}-$ where that means being wellmotivated by the aims and epistemic values of $\mathrm{P}$ if $\kappa$ is a relativized a priori kind in $\mathrm{P}$ or being warranted according to epistemic values of $\mathrm{P}$ to explain or predict observational laws of $\mathrm{P}$ if $\kappa$ is a properly empirical kind in $P$.

(G3) P is organized in such a way as to significantly increase its chance of obtaining long-term scientific progress, especially by having coherent and well-motivated aims, competitive predictive power, and using rigorous cross-checks.

Now that we have a full grip on what a genuine kind is, we can see how genuine kinds differ in a few final ways from the kinds of kinds race theorists talk about. For one, the agnostic kinds that race theorists talk about—specifically, natural ${ }_{i}$ kinds and natural $_{\mathrm{u}}$ kinds — $_{\text {- tend }}$ to differ from genuine kinds because they tend to be relativistic accounts of good scientific classification. 
For example, baramin counts as a natural ${ }_{i}$ kind and a natural ${ }_{u}$ kind because it is inductively useful and an object of study in baraminology, which is a contemporary scientific research program, albeit a fringe one. However, since baraminology does not count as a well-ordered SRP, baramin does not count as a genuine kind.

Finally, genuine kinds are authentically agnostic, unlike realist kinds, such as natural ${ }_{o}$ and real $_{i}$ biological kinds, and anti-realist kinds, such as natural ${ }_{\mathrm{p}}$ kinds. A particular genuine kind, such as, for example, monophyletic group in cladistics, could be an objectively real kind or a kind that is nothing more than a human construct. Genuine kind theory is silent on this matter. The only metaphysical fact that follows from a kind being genuine is that it is real enough to use in ongoing scientific research. This last point warrants further emphasis. By saying that a kind is genuine, one is committed to it being real in a certain sense, and that sense is 'real enough to use in ongoing scientific research'. What one is not committed to by saying that a kind is genuine is an ontological commitment to the kind being objectively real or not. The latter is an issue for philosophers engaged in the natural kind realism debate to work out.

Since genuine kinds are unique kinds of scientific kinds, genuine kinds can be used to underwrite an altogether new interpretation of 'biological racial realism'. Namely, 'biological racial realism' could mean that 'race is a genuine kind in biology'. Of course, all I have done so far is open up a new conceptual possibility. What remains to be seen is why we should adopt this new interpretation of 'biological racial realism' in the race debate. So let me move on to an argument that I think accomplishes just that.

\section{An Argument for Adopting Genuine Kinds in the Race Debate}


In the spirit of doing somewhat responsible analytic philosophy, below is a six-step argument for why 'biological racial realism' should mean 'race is a genuine kind in biology' in the race debate:

(1) The meaning of 'biological racial realism' in the race debate should be a metaphysically minimal interpretation of important scientific kindhood that also does the most justice to what counts as an important scientific kind.

(2) A "metaphysically minimal" interpretation of important scientific kindhood is one that does not adopt unnecessary and contentious metaphysical assumptions.

(3) The interpretation of important scientific kindhood that does the most justice to what counts as an important scientific kind is the one that best captures epistemically important scientific kinds—or 'EIS kinds' for short.

(4) The candidates for important scientific kindhood in the race debate are natural $_{\mathrm{o}}$ kinds, natural $\mathrm{i}_{\mathrm{i}}$ kinds, natural $\mathrm{u}_{\mathrm{u}}$ kinds, natural $\mathrm{p}_{\mathrm{p}} \mathrm{kinds}_{\mathrm{s}}$, real $_{\mathrm{p}}$ biological kinds, real ${ }_{i}$ biological kinds, and genuine kinds.

(5) No kind of kind in the race debate is both metaphysically minimal and does a better job of capturing EIS kindhood than genuine kinds.

(6) Therefore, the meaning of 'biological racial realism' in the race debate should be 'race is a genuine kind in biology'.

Now let me move on to what I consider to be adequate defenses of each premise of the above argument. Along the way I will raise and respond to salient objections to each premise.

First, (2) is just a stipulation. However, I think (1) is plausible for two reasons. First, the meaning of 'biological racial realism' in the race debate should be "metaphysically minimal" 
because, for one, it is just good philosophical method not to adopt contentious assumptions if doing so is unnecessary, and, as a matter of fact, adopting a contentious metaphysical interpretation of important scientific kindhood is unnecessary in the race debate. ${ }^{21}$

Several philosophers already agree with me on the stance that unnecessary and contentious metaphysical assumptions should not be adopted in the race debate. ${ }^{22}$ However, some race theorists agree with the maxim that we should not adopt unnecessary and contentious metaphysical assumptions in the race debate, and even agree that realist kindhood and anti-realist kindhood are contentious metaphysical accounts of important scientific kindhood, but disagree with (1) exactly because they believe it is necessary that we adopt a contentious interpretation of important scientific kindhood if we wish to engage in a worthwhile metaphysical debate about race. For example, consider Zack's reason for adopting natural ${ }_{\mathrm{o}}$ kinds to understand biological racial realism.

According to Zack $(2002,5)$, we ought to use a realist kind to understand biological racial realism exactly because the received view among ordinary people who believe in biological race is that race is an ontologically objective biological category. Thus, in order for the race debate to be relevant to ordinary people's concerns, we ought to use a realist kind to interpret 'biological racial realism'.

21 I see the reasoning that I am invoking here to be similar to John Rawls' motivation for developing a political conception of justice that does not depend upon a thick notion of the good, and to Arthur Fine's motivation for developing the natural ontological attitude in the scientific realism debate.

${ }^{22}$ For example, see Sundstrom (2002, 92-94), Kitcher (2007, 298-303), Haslanger (2008, 60), and Glasgow (2009, 80-83). 
While Zack's reason for adopting realist kinds in the race debate is commendable, I disagree with it on two grounds. For one, Zack's claim about ordinary people who believe in biological race requires empirical support, but Zack presents no empirical data to support her claim. Moreover, if she had presented empirical data, I doubt that the only plausible interpretation of the data would be that ordinary people who believe in biological race believe that race is objectively real. Since the notion of ontological objectivity is a technical notion in metaphysics, one could question whether ordinary people even think in terms of ontological objectivity. Rather, one could postulate that ordinary people who believe in biological race believe that race is biologically real qua being just as real as gene, cell, population, and other respectable biological kinds, which is compatible with an agnostic construal of biologically real kindhood.

Second, while it is commendable that Zack picks natural $\mathrm{l}_{\mathrm{o}}$ kinds to make the race debate relevant to ordinary people, metaphysical debates need not satisfy the concerns of ordinary people. As such, the race debate could be-and already seems to be-an esoteric debate in philosophy that satisfies the concerns of philosophers. For instance, some philosophers are interested in the race debate because they want to know whether race is biologically real. ${ }^{23}$ Others are interested because of its relevance for addressing social justice issues. ${ }^{24}$ However, notice that neither motivation requires that we adopt a contentious interpretation of 'biological racial realism', such as race being an objectively real biological kind, since we can use an agnostic kind to interpret 'biological racial realism'.

\footnotetext{
${ }^{23}$ Some examples are Appiah (1996), Andreasen (1998), and Zack (2002).

${ }^{24}$ Some examples are Sundstrom (2002), Kitcher (2007), and Haslanger (2008).
} 
With that said, a critic might still challenge whether our notion of important scientific kindhood should be metaphysically minimal exactly because one of the pressing queries that philosophers have about race is whether it is ontologically objective. I have no doubt that some philosophers are attracted to the race debate for this very reason. They acknowledge that curiosity about whether race is biologically real is a respectable motivation for engaging in the race debate, and they certainly would not disagree with engaging in the race debate as a step in achieving social justice. However, such critics are still skeptical about a race debate that is not at least in part asking whether race is objectively real.

To such critics I have the following reply. If ontologically objective kinds of living things exist, surely biology is our best bet at figuring out which kinds of living things are ontologically objective. So, if one is interested in the race debate only because she is interested in whether race is objectively real, she ought to be interested in whether race is biologically real. But also, it is actually unnecessary to require biological candidates for race to satisfy some description of ontological objectivity even if one is only interested in the race debate to figure out whether race is objectively real. How so?

Well, instead, we could use a less controversial description of the actual biological kinds considered to be ontologically objective kinds of living things (e.g. monophyletic group, deme, and cell) and ask whether race counts as a kind like that. In other words, we can use an agnostic kind theory to capture the extension that natural kind realists are interested in and then investigate whether race falls into that extension. In that way, race theorists can avoid the 
admittedly controversial metaphysical commitment to ontologically objective biological kinds while still addressing the curiosity that brings natural kind realists to the race debate. ${ }^{25}$

With that said, race theorists are at liberty to interpret biological racial realism using an agnostic understanding of important scientific kindhood while still engaging in a race debate worth having—both from the viewpoint of philosophers' concerns and ordinary people's. As such, it follows that adopting a contentious metaphysical interpretation of important scientific kindhood is unnecessary in the race debate. Now let me defend the rest of (1) and say a bit about why I think 'biological racial realism' should refer to a notion of scientific kindhood that does the most justice to what actually counts as important scientific kindhood.

By saying that the meaning of 'biological racial realism' should include a notion of scientific kindhood that does the most justice to what actually counts as important scientific kindhood, what I mean is that the notion of scientific kindhood that race theorists choose to interpret 'biological racial realism' should be one that best captures what counts as good classification in actual science. Otherwise, the race debate becomes a mere exercise in deciding whether race has an ontological status that is too disconnected with what is actually important in biology. Surely, this is not what the race debate should be about.

${ }^{25}$ In essence what I am suggesting is that we divert the question of whether race is objectively real to philosophers engaged in the natural kind realism debate, since it is up to them to figure out whether the special class of scientific kinds that appear to be objectively real actually consists of kinds that are objectively real. It is sufficient for those interested in the race debate to show that race either is or is not a member of the special class of scientific kinds that appear to be objectively real. 
For example, if the account of important scientific kindhood that race theorists adopt to interpret 'biological racial realism' implies that kinds like gene, cell, and protein do not turn out to be real biological kinds, but gemmule, baramin, and destructiveness organ do, then I would consider that result to be a reason in itself to reject the adopted account of important scientific kindhood since it is clearly far too disconnected from actual science.

My guess is that most race theorists would be on board with this constraint on theorizing about important scientific kindhood. In fact, race theorists are often interested in biological theories of race because of how biological theories of race are considered to be important in biology and influence how ordinary people are racialized and experience racial phenomena.

For example, recent efforts in biomedical research to develop a "genetic cluster" classification of race could, if successful, affect how drugs are tested and allocated among the public, with the most significant potential impact on ordinary people being race-targeted drugs. Furthermore, several race theorists have shown an interest in this debate exactly because of its potential impact on ordinary racial experience. ${ }^{26}$ So, in order to defend biological racial realism, the kind offered up as race should be, in some sense, important in doing respectable biology.

Now with that said, someone could be concerned that the second half of (1) defers too much to actual science, and the race debate would be better off adopting an account of important scientific kindhood that does the most justice to what philosophers consider to be important scientific kinds, regardless of how that definition hooks up with actual science. How might one reasonably adopt such a view? One way is to envision the race debate as merely "applied metaphysics" insofar as the race debate is just an especially high-profile portion of the

\footnotetext{
${ }^{26}$ For example, see Kitcher (2007) and Haslanger (2008).
} 
overarching project in contemporary metaphysics to figure out "the furniture of the world", as it is sometimes put.

Given such a view of the race debate, the relevant question about race with respect to its biological reality would not be 'Is race a legitimate kind in the study of life?', but rather, 'Is race an objectively real kind in the living world?' Furthermore, if we envision the race debate as in part addressing the latter instead of the former question, then it makes much more sense to define important scientific kindhood in terms of objective reality regardless of how that definition hooks up with actual science. In fact, given the right definition of 'objective reality', there might be no overlap among biological kinds and objectively real scientific kinds.

Though it is possible to envision a metaphysical debate about race as a debate that is not necessarily tied to what is going on in actual science, I disagree that the latter is the correct way to understand the race debate. The correct way to understand the race debate is not as a metaphysical debate with no necessary tie to what is going on in actual science, but rather, as a metaphysical debate that, in part, aims to explore whether race is biologically real in a way that connects with actual biology. This is not to say that one cannot have a metaphysical debate about race understood in a way that is disconnected with actual science. Rather, all I am saying is that such a debate about race would no longer be the same debate about race that philosophers have been engaging in since Kant, and that I have been calling 'the race debate' throughout this essay.

The reason why is because philosophers who are interested in the race debate are interested in, at least in part, whether race can be understood as a respectable kind in biology. To put it another way, it is a conversational presupposition of the race debate that when we are 
exploring the biological reality of race, we are exploring, at least in part, whether race is a respectable kind in the study of life.

Evidence for this presupposition is not hard to come by. For one, race theorists that adopt agnostic or anti-realist kinds to understand biological racial realism, such as Haslanger and Kitcher, see the race debate as a metaphysical debate more concerned with the biological reality of race as it relates to actual biology than a biological reality of race understood in a way that is substantially disconnected from biology. Second, even race theorists who adopt realist kinds to understand biological racial realism, such as Andreasen and Zack, pain themselves to adopt a kind of realist kind that adequately captures what is important in actual science. ${ }^{27}$

Finally, insofar as the race debate is one of the most interdisciplinary debates in contemporary philosophy, several biologists and anthropologists have weighed in on the race debate, and I am sure that all of them are interested in whether race is biologically real in a way that captures what is important in biology. So, with respect to (1), it is just good philosophical method to require that our account of important scientific kindhood in the race debate is metaphysically minimal; and it is just part of what the race debate is a debate about to articulate an account of important scientific kindhood that adequately captures important scientific kindhood in actual scientific practice. With (1) and (2) behind us, we can move on to (3).

Now (3) is perhaps the most contentious premise since it seems to bias the argument in favor of adopting genuine kinds in the race debate. But let me provide my rationale for adopting (3). When race theorists say that a kind is 'biologically real', they do not mean that the kind satisfies just any old important role in biology. As previously mentioned, a scientist could come up with a merely highly lucrative division, and so such a division would be economically

${ }^{27}$ For evidence, see Andreasen $(1998,207)$ and Zack $(2002,1-8)$. 
important, but no one would want to say that such a kind is important in science in any way that science is distinctively important.

Rather, since science is in the business of producing and securing a certain kind of knowledge about the empirical world, what is really important about a scientific kind is its epistemic importance to science. In other words, gene, electron, $\mathrm{H}_{2} \mathrm{O}$, and other important scientific kinds are important to science exactly because they enable scientists to answer questions about the world in the distinctively compelling way that science enables us to answer questions. Hence, the race debate should adopt an EIS kind to interpret 'biological racial realism'.

However, someone could challenge me by saying that what is really important about a scientific kind is not just that it is an EIS kind, but rather, that it is both an EIS kind and ontologically objective. As the critic might say, scientists care about what exists objectively in addition to what is useful in answering questions about the world. So, in order to adequately capture what scientists care about, we need to adopt a realist EIS kind in the race debate, or so the critic would say.

This is a good concern. And I agree that many scientists also care about what exists objectively in addition to what is epistemically useful. However, I have two remarks to make in response to this concern. First, the kinds of kinds that are important to science need not be identical with the kinds of kinds that scientists care about. This is just to say that what we are aiming to do in the race debate is use an interpretation of important scientific kindhood that does the most justice to what counts as an important kind in science; we are not aiming to use an interpretation of important scientific kindhood that does the most justice to what scientists 
believe counts as important scientific kindhood. The latter is because scientists can be confused or mistaken about which kinds are actually important in science.

The second point is that interpreting important scientific kindhood even partially in terms of ontological objectivity is out of the question in the race debate, since, as I have already made clear when defending (1), race theorists ought to adopt a metaphysically minimal interpretation of important scientific kindhood, and realist kinds are certainly not metaphysically minimal since realist kinds are contentious in the philosophy of science and entirely unnecessary in the race debate. Remember that adopting realist kinds in the race debate is unnecessary since we can address the concerns of ordinary people and race theorists by using an agnostic kind to understand biological racial realism. However, I have not yet explained why realist kinds are a contentious interpretation of important scientific kinds, so I will do that now.

There is a pretty straightforward reason for why natural kind realism is controversial. Namely, even if some kinds appear to be objectively real from the viewpoint of our most successful science, we would still need a meta-scientific argument to rule out—or at least show the implausibility of—-the following two metaphysical possibilities:

(M1) The world has no objectively real kinds but human thought or language evolved in such a way as to construct kinds anyway, some of which appear to be objectively real.

(M2) The world has objectively real kinds but human thought or language evolved in such a way as to dramatically mismatch humanly recognized kinds with the kinds that exist in objective reality.

However, whether any philosopher has or can provide such a meta-scientific argument is a matter of much controversy in contemporary philosophy of science, and even among scientific 
realists! For example, while Stathis Psillos (2002, xix) remains enthusiastic about natural kind realism, both Richard Boyd (1999, 174-175) and Ian Hacking (2007), who were both once proud defenders of natural kind realism, have abandoned it. Therefore, realist kinds are a contentious interpretation of important scientific kinds, and we should opt for interpreting important scientific kinds, for the purposes of the race debate, as just EIS kinds.

As for (4), I consider it uncontroversial given my literature review in $\$ 2$ and my introduction of genuine kinds in $\S 3$. However, one could worry that my argument is too shortsighted since there might be additional candidates for EIS kinds that philosophers outside of race theory have developed and that could be useful in the race debate.

This is a good concern, and I agree that philosophers outside of race theory have come up with EIS kinds that deserve at least some lip service. Specifically, there are a lot of other theories about natural kinds out there. ${ }^{28}$ There are also other pragmatic theories of EIS kind out there besides Kitcher's. ${ }^{29}$ However, I disagree that omitting other theories of EIS kind will make a difference to the argument that I am making. This is because other theories of EIS kind defend either realist, anti-realist, or agnostic kinds. However, as I have already shown, realist kinds are unnecessarily controversial kinds of EIS kinds, and as I will make clear when defending (5), anti-realist kinds are also unnecessarily controversial kinds of EIS kinds, and so both realist and anti-realist kinds are inappropriate for the race debate. Moreover, no other agnostic kind is as empirically adequate in capturing EIS kinds as genuine kinds, or so I will argue when defending (5).

${ }^{28}$ For a few of them see Wilkerson (1995), Boyd (1999), Griffiths (2004), La Porte (2004), and Häggqvist (2005).

${ }^{29}$ See, for example, Anderson (2005). 
Finally, (5) is plausible due to the following rationale. First, I have already made the case that realist kinds, such as natural ${ }_{\circ}$ kinds and real ${ }_{i}$ biological kinds, are not a metaphysically minimal interpretation of important scientific kindhood. But also, anti-realist kinds are not a metaphysically minimal interpretation of important scientific kindhood either, since adopting anti-realist kinds in the race debate is also unnecessarily controversial.

Specifically, natural kind anti-realism is just as controversial as natural kind realism because one would need to provide a thoroughly compelling meta-scientific argument that supports (M1) or (M2). However, whether such an argument has or can be made is also a matter of much dispute among philosophers of science. Furthermore, natural $\mathrm{p}_{\mathrm{p}}$ kinds are additionally controversial because they require moral justification in order to be real. But that seems to be an attack on the fact/value distinction which is controversial in its own right. Also, one need not adopt anti-realist kinds at all in the race debate, since agnostic kinds can be used.

Furthermore, agnostic kinds are a metaphysically minimal interpretation of important scientific kindhood, since whether natural kind realism is true or not, we are still going to need a theory of EIS kinds in order to explain how some kinds are epistemically useful in science while others are not. ${ }^{30}$ Insofar as agnostic kind theory is in the business of providing such an account, this class of scientific kind theory should not be seen as controversial, but rather, as part of any theory of important scientific kindhood that is worthy of the name.

Nevertheless, what can be debated is which agnostic view of important scientific kindhood best captures EIS kinds. Here is where I believe genuine kinds gain an advantage over natural $_{i}$ kinds, natural ${ }_{u}$ kinds, and real $l_{p}$ biological kinds. Genuine kind theory is simply more

\footnotetext{
${ }^{30}$ See Boyd (1999) for a similar view on what the minimal features should be for a good theory of scientific kinds.
} 
successful in predicting EIS kinds than natural ${ }_{\mathrm{i}}$ kind theory, natural ${ }_{\mathrm{u}}$ kind theory, and real $_{\mathrm{p}}$ biological kind theory. By that I mean genuine kind theory is better able to predict which kinds count as EIS kinds, such as gene, electron, and $\mathrm{H}_{2} \mathrm{O}$, and which kinds do not count as EIS kinds, such as baramin, gemmule, and destructiveness organ. Furthermore, since that is the sort of agnostic kind we want to interpret 'biological racial realism', we ought to understand biological racial realism as the view that race is a genuine kind in biology.

Specifically, and as explained in $\S 3$, natural $_{\mathrm{i}}$ kind theory fails to recognize scientific kinds that are just abductively useful as EIS kinds, such as superheavy elements in nuclear chemistry. Additionally, natural ${ }_{i}$ kind theory is extremely relativistic and designates kinds that are clearly not EIS kinds, such as baramin, to be EIS kinds in certain scientific contexts, such as baraminology.

As for natural $l_{u}$ kind theory, it is a bit too loose in its language to adequately capture EIS kinds. I agree that EIS kinds are useful objects of study in natural sciences, but I disagree that that is all there is to them. If that were the case, then, as I mentioned in $\S 3$, mere economic usefulness in a natural science would turn a kind into an EIS kind, but nobody thinks that that is the case. Rather, it is a kind's epistemic usefulness as a scientific kind-in my sense of the phrase — that turns a kind into a useful kind in a natural science. Furthermore, natural ${ }_{\mathrm{u}}$ kinds are also too relativistic to adequately capture EIS kinds, since, as I said earlier, given that baramin is a useful object of study in a natural science, namely, baraminology, it counts as a natural ${ }_{u}$ kind. However, baramin certainly is not an EIS kind.

This brings us to real $\mathrm{p}_{\mathrm{p}}$ biological kinds. At first glance it appears as though real $\mathrm{p}$ biological kinds are just a narrower version of genuine kinds. After all, genuine biological kinds will rest on "some biologically principled basis" (Glasgow 2009, 82). However, this is not quite 
correct because remember that a kind is not a real biological kind if it is "underdetermined by the biological facts" (Glasgow 2009, 106). Here is where I think genuine kinds better reflect EIS kinds than real $\mathrm{p}_{\mathrm{p}}$ biological kinds.

Relativized a priori kinds—-such as monophyletic group and higher taxon in cladisticsdo not count as real $\mathrm{p}_{\mathrm{p}}$ biological kinds, since they are certainly underdetermined by biological facts. Nevertheless, several relativized a priori kinds do count as EIS kinds. In contrast, genuine kind theory can and does recognize at least some relativized a priori kinds as EIS kinds. Actually, the situation is much worse than that.

If we take Duhem's underdetermination thesis seriously, as we should, then properly empirical kinds are also underdetermined by biological facts because they are justified in unison with factually underdetermined scientific theories. Rather, it is only through the epistemic values that scientists appeal to when justifying kinds that we ever have an adequate epistemic justification for adopting a kind in science. In that case, no biological kinds turn out to be real $\mathrm{p}_{\mathrm{p}}$ biological kinds. Of course, since genuine kind theory welcomes an appeal to epistemic values in our justifications of properly empirical kinds, properly empirical kinds can easily count as EIS kinds under genuine kind theory.

Once we couple genuine kind theory's superior ability to predict EIS kinds with its ontological neutrality in the natural kind realism debate, we can clearly see that the most appropriate interpretation of 'biological racial realism' in the race debate is 'race is a genuine kind in biology', since it is our best bet at achieving an interpretation that has the methodological virtues that we want in the race debate.

\section{Some Interesting Consequences of Adopting Genuine Kinds in the Race Debate}


Now let us get back to the race debate. If I am right that philosophers should adopt a genuine kind interpretation of 'biological racial realism' in the race debate, then substantial changes must be made to how philosophers defend biological racial realism as well as biological racial anti-realism. Let me start with the biological racial anti-realists.

If biologically real kinds should be understood as genuine biological kinds, then there are several defenses of biological racial anti-realism that are unconvincing because they adopt interpretations of biologically real kinds that are inappropriate for the race debate, either because they are not metaphysically minimal or because they do not adequately capture EIS kinds. A good example of a defense of the latter kind is Glasgow's (2009, 80-112) recent defense of biological racial anti-realism.

In a crucial part of Glasgow's argument for biological racial anti-realism he shows that two biological classifications of race-that he calls "superficial theory" and "genetic racial realism"- - do not carve out race as a biologically real kind because they fail to count as real $_{\mathrm{p}}$ biological kinds (Glasgow 2009, 84-91). However, since, as I explained earlier, no biological kinds count as real ${ }_{\mathrm{p}}$ biological kinds, Glasgow's anti-realist result is guaranteed from the start! Therefore, Glasgow only arrives at biological racial anti-realism by using a notion of biologically real kind that does not adequately capture epistemically important kinds in biology.

But also, if I am right that biologically real kinds should be understood as genuine biological kinds, then several defenses of biological racial realism turn out to be unconvincing as well because they fail to provide adequate evidence that their candidate for race is even a genuine biological kind. A prime example is Andreasen's cladistic race theory, which is supposed to be a theory of race from the viewpoint of cladistics. 
Cladistic race theory has two tenets. The first is that (R1) race, understood biologically, is cladistic subspecies (Andreasen 1998, 201, 209). The second is that (R2) cladistic subspecies are monophyletic groups of breeding populations in biological species (Andreasen 1998, 207210). Since cladistic subspecies is supposed to be a relativized a priori kind in cladistics, Andreasen takes the right approach when she defends its reality using "the principles of cladistic classification" (Andreasen 1998, 206). However, Andreasen's actual defense is inadequate because she does not explain how cladistic subspecies is supposed to be epistemically useful as a cladistic kind, and she does not outline how cladistic subspecies is well-motivated from a cladistic point of view. Let me be clear about what I mean here.

Andreasen (1998, 206-209) provides a good defense of cladistics as a well-ordered SRP and monophyletic group as a valid kind in cladistics, but she provides no justification for why biological species is a valid kind of species to use in cladistics, why it is justified to identify cladistic subspecies at every level in a conspecific monophyletic hierarchy, and why breeding population is a valid kind of population to use in cladistics.

Moreover, while we know that cladistic subspecies is supposed to be a presuppositional kind in cladistics, it is unclear how adopting cladistic subspecies is supposed to be epistemically useful as a presuppositional kind in cladistics. Does it promote cladistic aims? Does it improve cladistic predictive power? These are all questions that cladistic race proponents will need to address before we can deem cladistic subspecies a genuine biological candidate for race.

\section{Conclusion}

The objective of this paper was to defend the view that for the purposes of the race debate, 'biological racial realism' should mean 'race is a genuine kind in biology'. I advanced this view by outlining six current views of kindhood that race theorists use to underwrite six 
different views of biological racial realism. Next I introduced and clarified the idea of a genuine kind as a distinct seventh kind of kind that one could adopt in the race debate. Genuine kinds were defined as valid kinds in well-ordered SRPs, and more specifically, as kinds that satisfy (G1)-(G3). Next, it was argued that the race debate should adopt the best metaphysically minimal EIS kind among our seven kinds of kinds. Genuine kind was shown to be the best metaphysically minimal EIS kind, and so it was concluded that we should adopt a genuine kind interpretation of biological racial realism.

After addressing a few salient objections along the way, I finished by identifying a few interesting consequences of adopting genuine kinds in the race debate, such as rendering Glasgow's recent defense of biological racial anti-realism unpersuasive, and showing how cladistic subspecies is inadequately defended as a genuine cladistic kind. I hope this journey has resulted in a more promising way of asking and answering the question, 'Is race biologically real?'

\section{Acknowledgments}

I would like to thank several people for helpful comments, criticisms, and discussions that led to the final version of this paper. In alphabetical order I would like to thank Tom Dougherty, Michael Friedman, Jorge Garcia, Sally Haslanger, Chike Jeffers, Rae Langton, Micah Lewin, Helen Longino, Tommie Shelby, Elliott Sober, and Ward Watt. I would also like to thank the vibrant participants of the Work-In-Progress group in the Linguistics and Philosophy Department at the Massachusetts Institute of Technology (MIT) for helpful comments and criticisms that led to a revision of this paper. Finally, this research would not have been possible without a generous Martin Luther King Jr. Visiting Professor Fellowship from MIT as well as supplemental funding and a leave of absence from the University of San Francisco. 


\section{References}

Anderson, E. (2005). Knowledge, Human Interests, and Objectivity in Feminist Epistemology. Philosophical Topics 23(2): 27-58.

Andreasen, R. (2000). Race: Biological Reality or Social Construct? Philosophy of Science 67(S1): S653-S666.

Andreasen, R. (1998). A New Perspective on the Race Debate. British Journal for the Philosophy of Science 49(2): 199-225.

Appiah, K. (1996). "Race, Culture, Identity: Misunderstood Connections,” in K. Appiah and A. Gutmann (eds.), Color Conscious. Princeton: Princeton University Press, pp. 30-105.

Barrett, J. (2007). Dynamic Partitioning and the Conventionality of Kinds. Philosophy of Science 74(4): 527-546.

Blum, L. (2002). “I'm Not a Racist, But...”: The Moral Quandary of Race. Ithaca: Cornell University Press.

Boyd, R. (1999). "Homeostasis, Species, and Higher Taxa," in R. Wilson (ed.), Species, New Interdisciplinary Essays. Cambridge: MIT Press, pp. 141-185.

Buchwald, J., and Smith, G. (2001). Incommensurability and the Discontinuity of Evidence. Perspectives on Science 9(4): 463-498.

Friedman, M. (2001). Dynamics of Reason. Stanford: CSLI Publications.

Glasgow, J. (2009). A Theory of Race. New York: Routledge.

Goodman, N. (1978). Ways of Worldmaking. Indianapolis: Hackett.

Goodman, N. (1955). Fact, Fiction, and Forecast. Cambridge: Harvard University Press.

Griffiths, P. (2004). Emotions as Natural and Normative Kinds. Philosophy of Science 71(5): 901-911. 
Hacking, I. (2007). Natural Kinds: Rosy Dawn, Scholastic Twilight. Royal Institute of Philosophy Supplement, 82(61): 203-239.

Häggqvist, S. (2005). Kinds, Projectibility and Explanation. Croatian Journal of Philosophy 5(13): 71-87.

Haslanger, S. (2008). “A Social Constructionist Analysis of Race,” in B. Koenig, S. Lee, and S. Richardson (eds.), Revisiting Race in a Genomic Age. Piscataway: Rutgers University Press, pp. 56-69.

Kitcher, P. (2007). Does 'Race' Have a Future? Philosophy \& Public Affairs 35(4): 293-317.

Kitcher, P. (1999). “Race, Ethnicity, Biology, Culture,” in Leonard Harris (ed.) Racism: Key Concepts in Critical Theory (pp. 87-117). Amherst: Humanity Books.

La Porte, J. (2004). Natural Kinds and Conceptual Change. Cambridge: Cambridge University Press.

Longino, H. (1990). Science as Social Knowledge: Values and Objectivity in Scientific Inquiry. Princeton: Princeton University Press.

Machery, E., and Faucher, L. (2005). Social Construction and the Concept of Race. Philosophy of Science 72(5): 1208-1219.

Machery, E. (2005). Concepts Are Not a Natural Kind. Philosophy of Science 72(3): 444-467. Mayr, E. (2002). The Biology of Race and the Concept of Equality. Daedalus (winter): 89-94.

Newton, I. (1999). The Principia: Mathematical Principles of Natural Philosophy, I. Cohen and A. Whitman (trans.). Berkeley: University of California Press.

Psillos, S. (2002). Scientific Realism: How Science Tracks Truth. London: Routledge.

Risch, N., Burchard, E., Ziv, E., and Tang, H. (2002). Categorization of Humans in Biomedical Research: Genes, Race, and Disease. Genome Biology 3(7): comment2007.1-2007.12. 
Root, M. (2000). How We Divide the World. Philosophy of Science 67(3): S628-S639.

Smith, G.E. (2002). "The Methodology of the Principia," in I. Bernard Cohen and George E. Smith (eds.), The Cambridge Companion to Newton. Cambridge: Cambridge University Press, pp. 138-173.

Sober, E. (1993). Philosophy of Biology. Boulder: Westview Press.

Sundstrom, R. (2002). Race as a Human Kind. Philosophy \& Social Criticism 28(1): 91-115.

Taylor, P. (2004). Race: A Philosophical Introduction. Cambridge: Polity Press.

Wilkerson, T.E. (1995). Natural Kinds. Aldershot: Ashgate.

Zack, N. (2002). Philosophy of Science and Race. New York: Routledge. 